\title{
Post-harvest quality of lettuce cv. Elba in relation to Spirulina platensis foliar applications
}

\author{
Qualidade pós-colheita da alface cv. Elba em função de aplicações foliares de \\ Spirulina platensis
}

\author{
Débora Samara Oliveira e SILVA ; Railene Hérica Carlos ROCHA ${ }^{2}$; Jackson da Silva NÓBREGA; \\ George Alves DIAS ${ }^{4}$; José Franciraldo de LIMA ${ }^{5}$; Wellinghton Alves GUEDES ${ }^{6}$ \\ ${ }^{1}$ Engenheira agrônoma, Mestre em fitotecnia, Universidade Federal de Campina Grande - Centro de Ciência e Tecnologia \\ Agroalimentar (UFCG/CCTA), debora_samara2008@hotmail.com \\ ${ }^{2}$ Engenheira Agrônoma, Doutora em Fitotecnia, Professora da Universidade Federal de Campina Grande - Centro de Ciência \\ e Tecnologia Agroalimentar (UFCG/CCTA), raileneherica@ccta.ufcg.edu.br \\ ${ }^{3}$ Estudante de agronomia, Universidade Federal de Campina Grande - Centro de Ciência e Tecnologia Agroalimentar \\ (UFCG/CCTA), jacksonnobrega@hotmail.com \\ ${ }^{4}$ Estudante de agronomia, Universidade Federal de Campina Grande - Centro de Ciência e Tecnologia Agroalimentar \\ (UFCG/CCTA), george.alves.dias@hotmail.com \\ ${ }^{5}$ Biotecnólogo, Universidade de São Paulo. Fazenda Tamanduá. Caixa Posta 65, CEP:58700-970. Patos, PB. E-mail: \\ josefranciraldo@gmail.com \\ ${ }^{6}$ Autor para correspondência, Engenheiro agrônomo, estudante de Pós-graduação (Mestrado em Horticultura Tropical) \\ Universidade Federal de Campina Grande - Centro de Ciência e Tecnologia Agroalimentar (UFCG/CCTA), \\ wellinghton_guedes@hotmail.com
}

Recebido em: 04-08-2016; Aceito em: 15-12-2016

\begin{abstract}
Use of biomass extracted from microalgae has been increasing, with Spirulina platensis among them, which has been used for several purposes. In agriculture, it can be used as a biofertilizer or biostimulant, serving as a nutrients source and contributing to increase yield and food quality. Thus, the aim of this study was to evaluate the influence of successive Spirulina platensis applications on lettuce cv. Elba post-harvest quality. The experiment was conducted in a laboratory, using a completely randomized design in plots subdivided in time, with six repetitions. Plots referred to organic fertilizer concentrations (Spirufert $\circledast$ ) and subplots referred to evaluation periods (harvest and $24 \mathrm{~h}$ after harvest). Soluble solids (SS), $\mathrm{pH}$, titratable acidity, soluble solids/titratable acidity ratio, ascorbic acid, total chlorophyll $a$ and $b$ and protein were evaluated. Data were submitted to analysis of variance using Tukey's test at $5 \%$ probability level. There was significant effect between fertilizer concentrations and evaluation periods for most of the analyzed variables. Use of 7.5\% Spirufert ${ }^{\circledR}$ promotes quality characteristics maintenance for lettuce storage evaluated 24 hours after harvesting, preserving soluble solids content, titratable acidity, ascorbic acid, total chlorophyll and chlorophyll $a$.
\end{abstract}

Additional keywords: conservation; Lactuca sativa L.; microalgae.

\begin{abstract}
Resumo
É crescente o uso da biomassa extraída de microalgas, dentre elas a Spirulina platensis, a qual tem sido utilizada para diversas finalidades. Na agricultura, pode ser empregada como biofertilizante ou bioestimulante, servindo como fonte de nutrientes, contribuindo para o aumento da produtividade e para a qualidade dos alimentos. Nesse sentido, objetivou-se avaliar a influência de aplicações sucessivas de Spirulina platensis na qualidade póscolheita da alface cv. 'Elba'. O experimento foi conduzido em laboratório, utilizando delineamento inteiramente casualizado, em parcelas subdivididas no tempo, com seis repetições. As parcelas foram referentes às concentrações do fertilizante orgânico (Spirufert®), e as subparcelas, pelas épocas de avaliação (colheita e 24 h após a colheita). Avaliaram-se teores de sólidos solúveis (SS), pH, acidez titulável, relação sólidos solúveis/acidez titulável, ácido ascórbico, clorofila total, a e b, e proteína. Os dados foram submetidos à análise de variância e utilizouse o teste de Tukey, ao nível de $5 \%$ de probabilidade. Houve efeito significativo entre as concentrações do fertilizante e as épocas de avaliação, para a maioria das variáveis analisadas. O uso de Spirufert@ a 7.5\% promove manutenção nas características de qualidade para o armazenamento de alface avaliada $24 \mathrm{~h}$ após a colheita, preservando os teores de sólidos solúveis, de acidez titulável, de ácido ascórbico, de clorofila total e de clorofila a.
\end{abstract}

Palavras-chave adicionais: conservação; Lactuca sativa L.; microalgas. 


\section{Introduction}

Post-harvest quality refers to the set of characteristics that differentiate individual units of a product, being significant to determine the product acceptability degree by the buyer. In order to meet this demanding market, agricultural production must aim to produce quality food, with high nutritional value and higher post-harvest conservation (Yuri, 2004, Chitarra \& Chitarra, 2005, Teixeira et al., 2016). In this respect, agriculture is an expressive activity for Brazil, which has high production as a remarkable characteristic. However, high production is not characterized as a determining point, and alternatives to combine production increase with food quality are needed. The search for products that favor yield increase and quality improvement has been increasing in recent decades, and studies have pointed out that the various bioactive compounds in algae extracts are a promising alternative for the development of new biotechnology within organic agriculture (Limberger \& Gheller, 2012).

The microalgae Spirulina platensis comprises the filamentous cyanobacteria group, with high protein content and widely used as a single cell protein source for humans and animals (Aly \& Esaw, 2008; Monteiro et al., 2010). It is found in spiral shape, called tricoma, constituted by cylindrical cells, short and wide, covered by a thin membrane. The microalgae aforementioned has been the subject of research in several areas, such as biofuel production, human food supplementation, disease treatment, greenhouse mitigation, cosmetics manufacturing, pharmaceuticals, edible films and biodegradable packaging (Derner et al., 2006; Habib et al., 2008; Schmitz et al. 2012; Zeller et al., 2013) due to its composition.

In agriculture, it can be used as a biofertilizer by making nutrients available to the plants, contributing to increase the yield and quality of harvested food (Norrie, 2008; Chojnacka et al., 2012). However, there are few statistically proven studies that point out microalgae extracts efficiency on yield and food post-harvest quality aspects. Studies on Spirulina platensis in fresh products were carried out by Onias et al. (2016), and the authors reported efficacy in Spirulina platensis application when used in mango post-harvest coating. In pomegranates, coating with $3 \%$ cassava starch plus $3 \%$ Spirulina plantensis associated with refrigeration showed better biometric, visual and physicochemical quality in fruits during storage (Moreira, Rocha, 2015).

From this context, the aim of this study was to evaluate the influence of successive foliar applications of class "A" simple organic fertilizer, Tamanduá brand, based on Spirulina platensis (Spirufert $\AA$ ), in the postharvest quality of lettuce cv. Elba.

\section{Material and methods}

The research was carried out at the Federal University of Campina Grande (UFCG), in the Center of Food Sciences and Technology (CCTA), Pombal
Campus, PB State, from April to August 2014. 'Elba' cultivar was used, managed according to recommendations by Maldonade et al. (2014).

Seedlings were produced in greenhouse using expanded polystyrene trays consisting of 288 compartments, filled with commercial substrate (Baseplant@). Trays were laid on wooden benches, where they were sown at the rate of three seeds per cell. Thinning was performed at ten days and one seed was kept per compartment. Soil preparation was performed thirty days before seedlings transplanting, consisting of plowing followed by harrowing, at $20 \mathrm{~cm}$ depth. Then, seedbeds were built, which were $16,1 \mathrm{~m}$ long, $1,05 \mathrm{~m}$ wide and $20 \mathrm{~cm}$ high, shaded with sombrite at $50 \%$ in low-tunnel structures with a height of $1,20 \mathrm{~m}$ from the ground. Afterwards, soil samples were collected for physicochemical analysis, with another soil sample collection for analysis at the end of the experiment. Each plot was divided into six plots, with each plot consisting of 32 plants, spaced $0,25 \times 0,25 \mathrm{~m}$. Seedlings transplanting to the field was carried out 30 days after sowing, when plants had four definitive leaves. For irrigation management, drip system was used with frequency of four daily watering, 15 minutes each, reducing or suspending irrigation on rainy days. Periodically, manual weeding was carried out in the seedbeds with the intention of controlling weeds.

Treatments consisted of concentrations of $0 \%$, $1.5 \%, 3.0 \%, 4.5 \%, 6.0 \%$ and $7.5 \%$ of Spirufert ${ }^{\circledR}$ fertilizer (class "A" simple organic fertilizer, Tamanduá brand, based on Spirulina platensis) applied in the plots at late afternoon after irrigation, via foliar spraying, at 1, 7, 14, 21 and 28 days after transplanting (DAT) of the seedlings to the field. The product drainage point in the plant was considered as reference to the volume of syrup applied. Solutions preparation was carried out in the Laboratory of Soils and Plant Nutrition of CCTA by diluting the product in $800 \mathrm{~mL}$ of distilled water. After preparation of each solution, they were sieved and evaluated regarding $\mathrm{pH}$ using a digital peagometer, while electrical conductivity was evaluatedusing a benchtop conductivity meter $\left(25^{\circ} \mathrm{C}\right)$. Field application was performed through a $900-\mathrm{mL}$ capacity hand sprayer.

Plants were harvested manually between 5:00 A.M. and 7:00 A.M. using properly identified plastic boxes at 38 days after seedlings transplanting (DAT). They were transported to CCTA's Phytotechnology Laboratory, where they were washed in running water and exposed on a bench to drain excess water.

For lettuce quality and conservation evaluation under shelf conditions, a completely randomized design (DIC) was used in plots subdivided in time, with six repetitions, where each repetition consisted of three plants, totaling 18 plants per treatment. Plots consisted of six treatments $(0 \%, 1.5 \%, 3.0 \%, 4.5 \%, 6.0 \%$ and $7.5 \%$ Spirufert®) and subplots consisted of evaluation times (at harvest and 24h after lettuces storage in shelf, in air conditioned environment, at $26{ }^{\circ} \mathrm{C}$ and $70 \%$ $\mathrm{RH})$.

In order to determine soluble solids content, a 
digital refractometer (PR-100 model, Palette, Atago Co., LTD., Japan) was used, according to AOAC (1997), where two readings of the lettuce juice were carried out, obtained through grinding leaves in a food processor. Results were expressed as percentage (\%). Titratable acidity (TA) was determined by titration, in duplicate, using a $1 \mathrm{~mL}$ juice aliquot in which $49 \mathrm{~mL}$ of distilled water and 3 drops of $1 \%$ alcoholic phenolphthalein were added, using sodium hydroxide solution $(\mathrm{NaOH}) 0.1 \mathrm{~N}$, standardized with potassium biftalate, as titrant. Results were expressed in percentage (\%) of citric acid equivalent to the $\mathrm{NaOH}$ amount spent in the titration (AOAC, 1997).

Through reading, carried out directly from lettuce juice, hydrogenation potential $(\mathrm{pH})$ was evaluated using a Tecnopon digital peagometer (mPA210P Model/Version 7.1), according to the AOAC technique (1997). SS/AT ratio was estimated by the quotient between the two following constituents: soluble solids (SS) and titratable acidity (TA). Lettuce plants ascorbic acid content was evaluated in duplicate, according to the methodology proposed by Strohecker \& Henning (1967), taking $1 \mathrm{~mL}$ of the juice, diluting it in $49 \mathrm{~mL}$ oxalic acid and then performing titration with Tillmans solution. The results were expressed as mg of ascorbic acid per $100 \mathrm{~mL}$ of juice.

In order to determine chlorophyll, $0.2 \mathrm{~g}$ of grinded lettuce leaf was macerated in a mortar, with subsequent addition of $0.2 \mathrm{~g}$ sodium carbonate and $10 \mathrm{~mL}$ of acetone (80\% concentration), for disintegration. Samples were centrifuged at $1500 \mathrm{rpm}$ for $10 \mathrm{~min}$. After liquid extract cooling, aliquots were read in a spectrophotometer at 470, 646 and $663 \mathrm{~nm}$, using three repetitions per sample. From readings obtained in the spectrophotometer, chlorophylls $a, b$ and total chlorophyll contents were determined. Results were expressed as $\mathrm{mg} \mathrm{g}^{-1}$. Total protein analysis was performed in fresh matter, from the leaf macerate in the mortar, from which $0.2 \mathrm{~g}$ was obtained. Afterwards, samples were placed in digestion tubes, adding $1.5 \mathrm{~g}$ of catalytic mixture and $3 \mathrm{~mL}$ of sulfuric acid. Samples were then placed in the digester block and heated slowly, gradually rising to $400^{\circ} \mathrm{C}$, until the liquid became clear and transparent, with a blue-green hue. After digestion completion, $10 \mathrm{~mL}$ of distilled water plus $15 \mathrm{~mL}$ of sodium hydroxide were added to the digestion tubes, in order to initiate distillation in the Kjeldahl nitrogen distiller, containing $10 \mathrm{~mL}$ of boric acid. Subsequently, samples were titrated in triplicate with indicator solution (methyl orange and bromocresol green), and results were expressed in \%.

Data were submitted to the analysis of variance, performed by the computer software System for Analysis of Variance - SISVAR (Ferreira, 2011). There were no adjustments to the regression, and results presentation was carried out by means of tables, elaborated through Microsoft Excel 2013. Tukey's test at $5 \%$ probability level was used for mean comparison.

\section{Results and discussions}

There was no difference between treatments for any of the variables studied in relation to the different fertilizer concentrations (Spirufert®) applied, indicating that the lettuce cv. Elba quality was not affected by treatments (Table 1). Regarding interaction between the studied factors, fertilizer concentrations and evaluation dates, significant effect was observed for soluble solids, titratable acidity and SS/AT ratio variables at $1 \%$ probability level.

Table 1 - Summary of analysis of variance of soluble solids (SS), pH, titratable acidity (TA), and SS/TA ratio in lettuce cv. Elba sprayed during cultivation with different organic fertilizer (Spirufert®) concentrations, evaluated at harvest and after $24 \mathrm{~h}$ of storage at $26^{\circ} \mathrm{C}$.

\begin{tabular}{lccccc}
\hline Causes of & \multirow{2}{*}{ DF } & \multicolumn{4}{c}{ Mean square } \\
\cline { 3 - 6 } Variation & & \multicolumn{1}{c}{$\mathrm{SS}$} & $\mathrm{pH}$ & $\mathrm{TA}$ & $\mathrm{SS} / \mathrm{TA}$ \\
\hline Spirufert@ (S) & 5 & $1.222222^{\text {ns }}$ & $0.155556^{\mathrm{ns}}$ & $0.005766^{\mathrm{ns}}$ & $401.812942^{\mathrm{ns}}$ \\
Error (S) & 5 & 1.222222 & 0.155556 & 0.005766 & 401.812942 \\
Evaluation time (ET) & 1 & $4.500000^{* *}$ & $0.222222^{\text {ns }}$ & $0.338390^{* *}$ & $18527.804168^{* *}$ \\
S x ET & 5 & $0.700000^{* *}$ & $0.122222^{\text {ns }}$ & $0.010525^{* *}$ & $254.628085^{* *}$ \\
Error & 55 & 0.040404 & 0.137374 & 0.000846 & 2.760281 \\
CV (S, \%) & & 33.73 & 6.54 & 50.34 & 66.41 \\
CV (ET, \%) & & 6.13 & 6.15 & 19.28 & 5.50 \\
\hline General average & & 3.27 & 6.02 & 0.150 & 30.18 \\
\hline
\end{tabular}

Significant at $1 \%$; * significant at $5 \%$; ns not significant $5 \%$ by ' $F$ ' test; CV- coefficient of variation.

In the present experiment, it was verified that the lettuce cv. Elba soluble solids content, evaluated on the day of harvest (Table 2) and which received concentrations of $0 \%, 3.0 \%$ and $4.5 \%$ of fertilizer during cultivation, did not differ from each other. After the shelf period (24h), it was observed that the highest soluble solids content occurred with the application of $0 \%$ fertilizer (distilled water only), while the lowest content occurred in plants fertilized with $7.5 \%$ However, no significant differences were found between the other treatments. 
Table 2 - Soluble solids (SS) and titratable acidity (TA) in lettuce cv. Elba submitted to different organic fertilizer (Spirufert®) concentrations applied during field cultivation.

\begin{tabular}{|c|c|c|c|c|}
\hline \multirow{2}{*}{$\begin{array}{l}\text { Concentrations of } \\
\text { Spirufert }{ }^{\circledR}\end{array}$} & \multicolumn{2}{|c|}{ SS (\%) } & \multicolumn{2}{|c|}{ TA (mg100 $\mathrm{g}^{-1}$ citric acid) } \\
\hline & Day of harvest & $24 \mathrm{~h}$ after harvest & Day of harvest & $24 \mathrm{~h}$ after harvest \\
\hline $0 \%$ & 3.83 a $A$ & 3.33 a B & 0.069 b B & 0.183 с A \\
\hline $1.5 \%$ & $3.16 \mathrm{~b} \mathrm{~A}$ & $3.00 \mathrm{ab} A$ & $0.069 \mathrm{~b} \mathrm{~B}$ & $0.194 \mathrm{c} \mathrm{A}$ \\
\hline $3.0 \%$ & 4.00 a $\mathrm{A}$ & $3.00 \mathrm{ab} B$ & 0.148 a B & 0.194 c A \\
\hline $4.5 \%$ & 4.16 a $\mathrm{A}$ & $3.00 \mathrm{ab} B$ & 0.069 b B & 0.206 bc A \\
\hline $6.0 \%$ & 3.16 b A & $3.00 \mathrm{ab} A$ & $0.069 \mathrm{~b} \mathrm{~B}$ & $0.252 a b$ A \\
\hline $7.5 \%$ & $2.83 \mathrm{~b} \mathrm{~A}$ & $2.83 \mathrm{~b} \mathrm{~A}$ & $0.069 \mathrm{~b} \mathrm{~B}$ & 0.286 a $A$ \\
\hline $\begin{array}{l}\text { Regression Equation } \\
R^{2}\end{array}$ & $\begin{array}{c}\text { No adjustment } \\
\text {--- }\end{array}$ & No adjustment & $\begin{array}{c}\text { No adjustment } \\
\text {--- }\end{array}$ & $\begin{array}{c}\text { No adjustment } \\
\text {--- }\end{array}$ \\
\hline
\end{tabular}

Means followed by the same lowercase letter in the column and uppercase letter in the row do not differ significantly by Tukey's test at $5 \%$ probability level.

Silva et al. (2011) stated that, the higher the soluble solids content of freshly harvested lettuce, the longer its quality can be preserved, although this is not a lettuce quality characteristic, since the consumer does not expect to taste a sweet lettuce, unlike the expectation of savoring a typical dessert fruit, for example. When comparing soluble solids contents during the evaluation periods (Table 2), SS content reduction during storage (24h) was observed in plants that received foliar fertilization at the lowest concentrations, $0 \%, 3.0 \%$ and $4.5 \%$ of fertilizer. Decrease may have occurred due to leaf maturation progress process, which occurs due to carbohydrate consumption by metabolism through respiration (Neres et al., 2004; Reis et al., 2014). It is observed that the SS of lettuce plants that received the highest fertilizer concentrations during cultivation were kept constant during the period in which they remained in the shelf. In this respect, soluble solids maintenance during storage represents an indication of Spirulina platensis positive effect on lettuce quality components preservation.

According to table 2, it can be observed that the $3.0 \%$ foliar fertilizer concentration provided higher titratable acidity, $0.148 \mathrm{mg} 100 \mathrm{~g}^{-1}$, equivalent to fresh matter citric acid. After storage, the lowest organic acid levels occurred in plants that received concentrations of $0 \%, 1.5 \%$ and $3.0 \%$. According to Nunes et al. (2013), this fact can be attributed to the own plant consumption, which used organic acids as energy source to remain alive, in order to maintain its metabolic functions active, resulting in titratable acidity reduction. In this respect, the higher TA content observed in plants that received $7.5 \%$ of Spirulina-based fertilizer may indicate longer shelf life for plants in this treatment due to substrate maintenance. According to Souza (2010), citric acid contents are usually modified after a few days of storage, due to factors such as respiration and microorganisms, what may change these concentrations for more or less. When comparing organic acid contents present in lettuce plants at harvest and after storage, tendency of citric acid content increase in the fresh matter of plants that received different fertilizer concentrations after permanence on shelf for 24 hours was observed. According to table $3, \mathrm{pH}$ values of lettuce plants evaluated on the day of harvest and 24 hours after harvest, kept in shelf, did not vary according to treatments, evidencing that the product used did not interfere in this characteristic. When comparing lettuce hydrogenation potential in the evaluation periods, $\mathrm{pH}$ decrease was observed in plants that received $1.5 \%$ Spirufert $\AA$ and were kept in shelf in the laboratory for 24 hours. There was no statistical difference for the other concentrations. Taiz \& Zeiger (2013), reported that plants chemical composition may vary between different species and even within a species according to the environmental conditions to which they are submitted.

Table 3 - Lettuce cv. Elba $\mathrm{pH}$ and SS/TA ratio when submitted to different organic fertilizer (Spirufert $\AA$ ) concentrations, applied during field cultivation.

\begin{tabular}{ccccc}
\hline Concentrations of & \multicolumn{2}{c}{$\mathrm{pH}$} & \multicolumn{2}{c}{ Relation SS/TA } \\
\cline { 2 - 5 } Spirufert $\AA$ & Day of harvest & $24 \mathrm{~h}$ after harvest & Day of harvest & $24 \mathrm{~h}$ after harvest \\
\hline $0 \%$ & $6.00 \mathrm{a} \mathrm{A}$ & $5.83 \mathrm{a} \mathrm{A}$ & $55.58 \mathrm{~b} \mathrm{~A}$ & $17.87 \mathrm{a} \mathrm{B}$ \\
$1.5 \%$ & $6.50 \mathrm{a} \mathrm{A}$ & $6.00 \mathrm{a} \mathrm{B}$ & $45.38 \mathrm{c} \mathrm{A}$ & $16.22 \mathrm{ab} \mathrm{B}$ \\
$3.0 \%$ & $6.00 \mathrm{a} \mathrm{A}$ & $6.00 \mathrm{a} \mathrm{A}$ & $33.93 \mathrm{e} \mathrm{A}$ & $15.04 \mathrm{ab} \mathrm{B}$ \\
$4.5 \%$ & $6.00 \mathrm{a} \mathrm{A}$ & $6.00 \mathrm{a} \mathrm{A}$ & $59.95 \mathrm{a} \mathrm{A}$ & $13.99 \mathrm{bc} \mathrm{B}$ \\
$6.0 \%$ & $6.00 \mathrm{a} \mathrm{A}$ & $6.00 \mathrm{a} \mathrm{A}$ & $44.90 \mathrm{c} \mathrm{A}$ & $12.05 \mathrm{~cd} \mathrm{~B}$ \\
$7.5 \%$ & $6.00 \mathrm{a} \mathrm{A}$ & $6.00 \mathrm{a} \mathrm{A}$ & $37.62 \mathrm{~d} \mathrm{~A}$ & $9.67 \mathrm{~d} \mathrm{~B}$ \\
\hline Regression & No adjustment & No adjustment & No adjustment & $\mathrm{Y}=19.603556-1.559667 \mathrm{x}$ \\
Equation & --- & --- & --- & 0.9793 \\
$\mathrm{R}^{2}$ & & &
\end{tabular}

Means followed by the same lowercase letter in the column and uppercase letter in the row do not differ significantly by Tukey's test at $5 \%$ probability level. 
Table 3 shows the highest ratio between soluble solids content and titratable acidity in lettuces analyzed on the day of harvest, corroborating with the values recorded for soluble solids and acidity (Table 2 ), since on the day of harvest, plants had higher soluble solids content and lower acidity compared to lettuces analyzed after 24 hours of harvest. The lowest SS/AT ratio, observed after storage, was attributed to titratable acidity increase in all treatments, and this reduction was more evident in lettuces that received concentrations above $4.5 \%$. This fact can lead to bitter taste, an undesirable characteristic for the consumer, which is related to accumulation of substances such as acids, phenols and alcohol from deteriorating processes, associated with high concentration of the product applied on the leaves. Deteriorating processes may limit lettuce gas exchange and respiration, triggering fermentation and senescence more quickly.

According to table 4 , in which chlorophyll a, chlorophyll $b$, total chlorophyll, protein and ascorbic acid were analyzed according to the different fertilizer concentrations, it was verified in the analysis of variance that there was no difference between treatments for any of the studied variables. As for interaction between the studied factors, significant effect was observed for ascorbic acid, chlorophyll $a$, chlorophyll $b$ and total chlorophyll variables, with the exception of the protein variable.

Table 4 - Summary of analysis of variance of ascorbic acid, total chlorophyll, chlorophyll $a$, chlorophyll $b$ and protein in lettuce cv. Elba sprayed during cultivation with different organic fertilizer (Spirufert®) concentrations, evaluated at harvest and after $24 \mathrm{~h}$ of storage in shelf at $26^{\circ} \mathrm{C}$. t.

\begin{tabular}{lcccccc}
\hline $\begin{array}{l}\text { Causes of } \\
\text { variation }\end{array}$ & DF & \multicolumn{5}{c}{ Mean Square } \\
\cline { 3 - 7 } & & Ascorbic acid & Total chlorophyll & Chlorophyll $a$ & Chlorophyll $b$ & Protein $^{1}$ \\
\hline Spirufert® (S) & 5 & $0.191449^{\mathrm{ns}}$ & $10465.300767^{\mathrm{ns}}$ & $982.2815^{\mathrm{ns}}$ & $2307.522245^{\mathrm{ns}}$ & $0.256862^{\mathrm{ns}}$ \\
Error (S) & 5 & 0.191449 & 10465.300767 & 982.2815 & 2307.522245 & 0.256862 \\
Evaluation time (ET) & 1 & $4.743200^{* *}$ & $27828.336806^{* *}$ & $103710.5196^{* *}$ & $1832.444901^{\text {ns }}$ & $0.766735^{* *}$ \\
Sx ET & 5 & $0.587253^{*}$ & $6341.983992^{* *}$ & $5994.3565^{*}$ & $3957.872105^{* *}$ & $0.104765^{\text {ns }}$ \\
Error & 55 & 0.135129 & 887.553348 & 2387.9471 & 536.317856 & 0.098913 \\
CV (S, \%) & & 7.63 & 50.03 & 19.71 & 87.65 & 32.88 \\
CV (ET, \%) & & 6.41 & 14.57 & 30.73 & 42.25 & 20.41 \\
\hline General average & & 5.73 & 3.27 & 6.02 & 0.150 & 30.18 \\
\hline
\end{tabular}

** Significant at $1 \%$; * significant at $5 \%$; ns not significant at $5 \%$ by ' $\mathrm{F}$ ' test; CV- coefficient of variation. ${ }^{1}$ Analysis performed only at harvest.

In the comparison between harvest and storage period ( $24 \mathrm{~h}$ ), there was ascorbic acid reduction in plants evaluated $24 \mathrm{~h}$ after harvest at the different fertilizer concentrations, except for plants that received $7.5 \%$, which were not significantly different. This could be an indicative of positive effect of the product in preserving ascorbic acid in lettuce. Ascorbic acid is a factor used as product degradation indicator because it is extremely unstable and easily oxidized in contact with the environment due to sensitivity to oxygen interaction, causing decrease of its normal value (Nunes et al., 2013).

Regarding total chlorophyll content (Table 5), evaluated on harvest day, there were significant differences regarding treatment application, with concentrations of 6.0 and $7.5 \%$ promoting the highest chlorophyll content (220.17 and $233.54 \mathrm{mg} \mathrm{g}^{-1}$, respectively) in relation to treatments with 0 and $1.5 \%$ fertilizer. Meanwhile, foliar fertilizer concentration of $1.5 \%$ provided the lowest total chlorophyll content $\left(114.15 \mathrm{mg} \mathrm{g}^{-1}\right)$. This fact could probably be related to the amino acids found in the Spirulina-based fertilizer or to the nitrogen absorbed when the lettuce plants stomata were open, favoring plant positive performance by acting in chlorophyll synthesis. This effect can also be observed in lettuce plants analyzed $24 \mathrm{~h}$ after harvest, when foliar fertilization at the concentration of $6.0 \%$ held the highest total chlorophyll content. Plants that received 3.0\% of fertilizer had their total chlorophyll reduced. Considering the evaluation periods, it was observed that plants that were in shelf for 24 hours had higher chlorophyll content in relation to plants evaluated on the day of harvest for the different product concentrations, except for those that received 3.0 and $7.5 \%$ fertilizer concentrations, which held chlorophyll levels. Chlorophyll retention is an important parameter to determine the final quality of green vegetables, as the two chlorophyll forms are very sensitive to heat, oxygen, light, enzymes and metal action (Silva et al., 2015).

Table 6 shows chlorophyll $a$ and $b$ values. It can be observed that chlorophyll a contents were not significantly different in relation to treatments and different evaluation periods, with mean values ranging from 92.59 to $144.85 \mathrm{mg} \mathrm{g}^{-1}$ on the day of harvest and 163.48 to $231.13 \mathrm{mg} \mathrm{g}^{-1}$ for plants kept in shelf for $24 \mathrm{~h}$, respectively. When comparing evaluation periods, chlorophyll a content of lettuce plants that received 1.5, 4.5 and $6.0 \%$ fertilizer concentrations and were kept for 24 hours in the shelf, stood out in relation to the plants analyzed on the day of harvest. 
Table 5 - Lettuce cv. Elba ascorbic acid and total chlorophyll when submitted to different organic fertilizer (Spirufert@) concentrations, applied during field cultivation.

\begin{tabular}{|c|c|c|c|c|}
\hline \multirow{2}{*}{$\begin{array}{l}\text { Concentration of } \\
\text { Spirufert® }\end{array}$} & \multicolumn{2}{|c|}{ Ascorbic acid $\left({\left.\mathrm{mg} 100 \mathrm{~g}^{-1}\right)}\right.$} & \multicolumn{2}{|c|}{ Total chlorophyll } \\
\hline & Day of harvest & $24 \mathrm{~h}$ after harvest & Day of harvest & $24 \mathrm{~h}$ after harvest \\
\hline $0 \%$ & 6.16 a $A$ & $5.57 \mathrm{a} \mathrm{B}$ & 163.77 bc B & 221.71 bc $A$ \\
\hline $1.5 \%$ & 6.16 a $A$ & 5.13 a B & 114.15 с B & $212.14 \mathrm{bc} \mathrm{A}$ \\
\hline $3.0 \%$ & 6.16 a $A$ & 5.57 a B & $183.64 \mathrm{ab} A$ & 191.71 с A \\
\hline $4.5 \%$ & 6.16 a $A$ & 5.42 a B & $193.51 \mathrm{ab} B$ & $244.33 \mathrm{ab} A$ \\
\hline $6.0 \%$ & $5.86 a b$ A & 5.42 a B & 220.17 a B & 275.53 a A \\
\hline $7.5 \%$ & $5.42 \mathrm{~b} \mathrm{~A}$ & 5.72 a $A$ & 233.54 a A & 199.29 bc A \\
\hline $\begin{array}{l}\text { Regression } \\
\text { Equation }\end{array}$ & $\begin{array}{c}Y=5.881333+0.291762 x- \\
-0.060238 x^{2}\end{array}$ & No adjustment & $Y=117.121111+19 \cdot 337381 x$ & No adjustment \\
\hline $\mathrm{R}^{2}$ & 0.9613 & --- & 0.7161 & --- \\
\hline
\end{tabular}

Means followed by the same lowercase letter in the column and uppercase letter in the row do not differ significantly by Tukey's test at $5 \%$ probability level.

Observing data in Table 6, there is chlorophyll $b$ content increase in the plants analyzed on the day of harvest with fertilizer application at concentrations of 6.0 and $7.5 \%$. Among the other treatments, concentrations of 0 and $1.5 \%$ resulted in the lowest content of this pigment. Total chlorophyll had a similar result, where possibly nitrogen or amino acid absorption occurred in the fertilizer solution, acting on chlorophyll synthesis. On the other hand, treatments did not interfere significantly in chlorophyll $b$ content for plants that were kept $24 \mathrm{~h}$ in shelf, where means ranged from 38.94 to $56.87 \mathrm{mg} \mathrm{g}^{-1}$. When analyzing lettuce plants behavior regarding chlorophyll $b$ content during evalu- ation periods, it is verified that plants evaluated 24 hours after harvest and which received $1.5 \%$ of fertilizer during production process had better chlorophyll $b$ contents in relation to the plants analyzed on the day of harvest. However, reduction of this pigment was observed in plants that had 4.5, 6.0 and $7.5 \%$ fertilizer concentration applied. This was possibly caused by the fertilizer absorbed by lettuce plants, interfering in chlorophyll $b$ degradation, which is not a desirable feature for lettuce marketing. It is worth mentioning that chlorophyll is an important parameter, as chlorophyll $a$ and b levels are directly related to green coloration in plants.

Table 6 - Lettuce cv. Elba chlorophyll $a$ and chlorophyll $b$ when submitted to different organic fertilizer (Spirufert@) concentrations, applied during field cultivation.

\begin{tabular}{|c|c|c|c|c|}
\hline \multirow{2}{*}{$\begin{array}{l}\text { Concentration of } \\
\text { Spirufert® }\end{array}$} & \multicolumn{2}{|c|}{ Chlorophyll $a$} & \multicolumn{2}{|c|}{ Chlorophyll $b$} \\
\hline & Day of harvest & $24 \mathrm{~h}$ after harvest & Day of harvest & $24 \mathrm{~h}$ after harvest \\
\hline $0 \%$ & 144.57 a $A$ & 200.23 a A & 33.24 c A & 55.02 a $A$ \\
\hline $1.5 \%$ & 92.59 a B & 231.13 a A & 21.62 с B & 56.87 a $\mathrm{A}$ \\
\hline $3.0 \%$ & 144.09 a A & 185.81 a $A$ & $41.47 \mathrm{bc} \mathrm{A}$ & 46.30 a $A$ \\
\hline $4.5 \%$ & 98.21 a B & 197.40 a A & $79.26 \mathrm{ab} A$ & 47.05 a B \\
\hline $6.0 \%$ & 102.03 a B & 203.73 a A & 85.99 a A & 54.36 a B \\
\hline $7.5 \%$ & 144.85 a A & 163.48 a A & 97.50 a $A$ & 38.94 a B \\
\hline $\begin{array}{c}\text { Regression } \\
\text { Equation } \\
\mathrm{B}^{2}\end{array}$ & No adjustment & No adjustment & $Y=4.630333+15.777524 x$ & No adjustment \\
\hline $\mathrm{R}^{2}$ & --- & --- & 0.8738 & --- \\
\hline
\end{tabular}

Means followed by the same lowercase letter in the column and uppercase letter in the row do not differ significantly by Tukey's test at $5 \%$ probability level.

\section{Conclusions}

Use of $7,5 \%$ Spirufert@ keeps quality characteristics of lettuce stored and evaluated 24 hours after harvesting, preserving soluble solids contents, titratable acidity, ascorbic acid, total chlorophyll and chlorophyll $a$.

\section{References}

Aly MS, Esaw MA (2008) Evaluation of Spirulina Platensis as Bio Stimulator for Organic Farming Systems. Journal of Genetic Engineering and Biotechnology 6(1):1-7.
AOAC - Association of Official Analytical Chemists (1997) Official methods of analysis of AOAC International. (ed.) Gaitheersburg: AOAC, 1997.

Chitarra MLF, Chitarra AB (2005) Pós-colheita de frutas e hortaliças: Fisiologia e manuseio. Ed. UFLA, Lavras, Brasil, 783p.

Chojnacka K, Saeid A, Michalak I (2012) The possibilities of the apllication of algal biomass in the agriculture. Chemik 66(11):1235-1248.

Derner RB, Ohse S, Villela M, Carvalho SM, Fett R (2006) Microalgas, Produtos e Aplicações. Ciência Rural 36(6):1959-1967. 
Ferreira DF (2011) Sisvar: a computer statistical analysis system. Ciência \& Agrotecnologia 35:1039-1042.

Habib MAB, Parvin M, Huntington TC, Hasan MR (2008) A Review on Culture, Production and Use of Spirulina as Food for Humans and Feeds for Domestic Animals and Fish. FAO Fisheries and Aquaculture Circular. 33p.

Limberger P, Gheller JA (2012) Efeito da aplicação foliar de extratos de algas, aminoácidos e nutrientes via foliar na produtividade e qualidade de alface crespa. Revista Brasileira de Energias Renováveis 1:148-161.

Maldonade LR, Mattos LM, Moretti CL (2014) Manual de boas práticas na produção de Alface. Brasília, DF: Embrapa Hortaliças, 44p.

Monteiro MPC, Luchese, RH, Absher, TM (2010) Effect of Three Different Types of Culture Conditions on Spirulina maxima Growth. Brazilian Archives of Biology and Technology 53(2):369-373.

Moreira IS, Rocha RHC (2015). Estudo da qualidade da romã 'Molar'. Editora Novas Edições Acadêmicas. $85 p$.

Neres CRL, Vieira G, Diniz ER, Mota WF, Puiatti M (2004) Conservação do jiló em função da temperatura de armazenamento e do filme de polietileno de baixa densidade. Bragantia 63(3):431-438.

Norrie J (2008). Advances in the use of Ascophyllum nodosum seaplant extracts for crop production. Laboratory and Field Research. Disponível em <http://www.fluidfertilizer.com>. Acesso em: 18 de fevereiro de 2014.

Nunes CJS, Souza ML, Ferreira RLF (2013) Qualidade e pós-colheita da rúcula orgânica armazenada sob refrigeração. Enciclopédia Biosfera 9(17):2231.

Onias EA, Rocha RHC, Lima JF, Onias EA, Furtunato TCS (2016). Organic 'Tommy Atkins' mango postharvest quality when treated with biofilms enriched by Spirulina platensis. Científica 44(3):286-293.
Reis HF, Melo CM, Melo EP, Silva RA, Scalon SPQ (2014) Conservação pós-colheita de alface crespa, de cultivo orgânico e convencional, sob atmosfera modificada. Horticultura Brasileira 32(3):303-309.

Schmitz R, Magro C, Colla LM (2012) Aplicações ambientais de microalgas. Revista Ciências Exatas Aplicadas e Tecnológicas 4(1):48-60.

Silva EMNCP, Ferreira RLF, Araújo Neto SE, Tavella LB, Solino AJS (2011) Qualidade de alface crespa cultivada em sistema orgânico, convencional e hidropônico. Horticultura Brasileira 29(2):242-245.

Silva APG, Borges CD, Miguel ACA, Jacomino AP, Mendonça CRB (2015) Características físico-químicas de cebolinha comum e europeia. Brazilian Journal Food Tecnology 18(4):293-298.

Souza JF (2010) Alterações bioquímicas e fisiológicas de salada mista minimamente processada composta por alface americana, alface roxa e acelga, 127f. Ufs (Dissertação Mestrado).

Strohecker R, Henning HM (1967) Análises de vitaminas: métodos comprovados. Madrid, Espanha, 428p.

Taiz L, Zeiger E (2013) Fisiologia vegetal. 33 ${ }^{\underline{a}}$ (ed.) Artmed, Porto Alegre, Brasil, 918p.

Teixeira DA, Gomes JAO, Bonfim FPG, Pardo PI, Mayobre MT (2016) Técnicas de conservação póscolheita para o manjericão. Revista Brasileira de Plantas Medicinais 18(1):168-171.

Yuri JE (2004) Produção, nutrição e conservação póscolheita da alface tipo americana, cv. Raider, no verão e no inverno, em função da aplicação de nitrogênio e potássio em Cobertura, 139f. Ufla (Tese de Doutorado em Agronomia).

Zeller MA, Hunt R, Jones A, Sharma S (2013) Bioplastics and their thermoplastic blends from Spirulina and Chlorella microalgae. Journal of Applied Polymer Science 130(5):3264-3275. 